\title{
水銀漸次繰返し圧入法で抽出するモルタル硬化体のインクボトル空隙および 連続空隙に関する一考察
}

\author{
吉田亮 ${ }^{* 1}$ 水野浩平 ${ }^{*}$ 岸利治 ${ }^{*} 3$ 梅原秀哲 ${ }^{* 2}$
}

\begin{abstract}
*1 名古屋工業大学 大学院社会工学専攻 (
*2 名古屋工業大学 大学院創成シミュレーション専攻 (厂466-8555 愛知県名古屋市昭和区御器所町)

*3 東京大学 生産技術研究所人間・社会系部門 ( T 153-8505 東京都目黒区駒場 4-6-1)
\end{abstract}

\begin{abstract}
要旨：モルタル硬化体において水銀漸次繰返し圧入法で得るインクボトル空隙と連続空隙の実態を把握す るため、他の空隙分析手法を用いて下記の検証を行った。インクボトル空隙に関しては、空気泡の量と寸 法を調整した試料を用いてリニアトラバース法で得る空気泡との間に扔ける量的関係を検討した。また連 続空隙に関しては、セメント・混和材種類の異なる試料を用いた吸水・乾燥過程の質量変化との関係につ いて定量的に検討を行った。インクボトル空隙は空気泡の量との間に強い相関関係を確認できた。また連 続空隙は、吸水・乾燥開始直後から数時間の間に観察される急激な質量変化 (1 時間の吸水量、 3 時間の 乾燥量)との間に強い相関関係が確認できた。
\end{abstract}

キーワード：水銀圧入法、インクボトル、空気泡、リニアトラバース法、吸水

\section{1. はじめに}

水銀圧入法で得るしきい空隙径と総空隙量はコンク リートの透水係数との間に強い相関関倸があることが Mehta らによって示されている1)。しかし水銀圧入法に は、インクボトル効果による微小空隙の過大評価や過剩 圧力による試料の変形などの問題が挙げられており、セ メント硬化体の空隙構造を正しく評価できていないとい うことが述べられている2)。

一方で水銀圧入法には非圧縮性の水銀が空隙へ再び圧 入される際の履歴曲線が、必ず過去の履歷曲線をたどる という厳密な規則性を持つことが報告されている3)。こ の規則性を応用し、経験最高圧力を漸次更新し厓と排 出のサイクルを繰り返した際の圧入履歴から、履歴曲線 の重複部(包絡線)を連続空隙とし、また圧力を更新した 際に包絡線から分岐した差分をインクボトル空隙として 分離抽出する手法を提案した4)。また本提案手法では、 過剩圧力が与えられた際に観察される包絡線から乘離す る履歴曲線の圧力段階を読み取ることで、適切な測定圧 力範囲を判定することができる。

本研究では水銀漸次繰返し圧入法で分離抽出されるイ ンクボトル空隙と連続空隙の実態把握を行うため、イン クボトル空隙量に関しては、リニアトラバース法を用い てモルタル硬化体の空気泡量との関係について検証し、 また水銀の圧入・排出が可能な連続空隙量に関してはモ ルタル硬化体の吸水過程、そして吸水後の乾燥過程に掠 ける質量変化から吸水・乾燥が可能な水の移動経路との 関係について検討を行う。

\section{2. 実験概要}

本研究では 2.1 および 2.2 に示す 2 つの実験シリー ズを設け、水銀漸次繰返し圧入法で得るインクボトル空 隙と連続空隙の定量的な検証を行う。

\section{1 水銀漸次繰返し圧入法で得るインクボトル空隙量} とリニアトラバース法で得る空気量の関係

\section{（1）供試体概要}

モルタルは水道水、普通ポルトランドセメント、石灰 石砕砂を用いて、水：セメント：砂の質量比を $0.5: 1$ : 2.5 として作製した。 $\mathrm{AE}$ 片にはアルキルエーテルサル フェート系 $(\mathrm{M}) 、$ 、ロジ塩系 $(\mathrm{L}) 、$ 小よびアルキルリン 酸エステル系 $(\mathrm{S})$ の 3 種類を用いて連行空気の寸法を調 整した(寸法シリーズ)。連行された空気泡の寸法は後述 する画像解析により確認するが、ここでは予想される寸 法により L、M、S と呼ぶことにする。またフレッシュ 時の目標空気量を $\mathrm{AE}$ 郕 $\mathrm{M}$ では 3.5.6.7.5\%の 3 水準、 $\mathrm{AE}$ 片 $\mathrm{L}$ および $\mathrm{S}$ では $6 \%$ の基準を設け、添加量を調 整して打設した(量シリーズ)。Table 1 に供試体種別と 空気量の関係を示す。供試体は $\phi 100 \times 200 \mathrm{~mm}$ の円柱型 枠に打設し、材齢 3 日で脱型を行い材齢 28 日まで水中 養生を行い作製した。

（2）試験および測定方法概要

空気量は $\phi 100 \times 200 \mathrm{~mm}$ の円柱供試体の中央部分から 厚さ $40 \mathrm{~mm}$ 程度の円盤を切り出し、表面を研磨した後 にリニアトラバース法を行い算出した。

また、空隙構造分析は水銀漸次繰返し圧入法 ${ }^{4)}$ によ y $0 \rightarrow 1(1,000) \rightarrow 0.3(4,000) \rightarrow 4(320) \rightarrow 0.3 \rightarrow 13(100)$ 
Table 1 AE agent types and amount of air

\begin{tabular}{|c|c|c|c|c|c|c|}
\hline \multirow{3}{*}{ Mixture } & \multirow{3}{*}{$\mathrm{W} / \mathrm{C}$} & \multicolumn{2}{|c|}{ AE agent } & \multicolumn{2}{|c|}{$\operatorname{Air}(\%)$} & \multirow{3}{*}{$\begin{array}{l}\text { Air void } \\
\text { spacing } \\
\text { factor } \\
(\mu \mathrm{m})\end{array}$} \\
\hline & & \multirow{2}{*}{ type } & dosage & \multirow{2}{*}{$\begin{array}{l}\text { fresh } \\
\text { mortar }\end{array}$} & \multirow{2}{*}{$\begin{array}{c}\text { hardened } \\
\text { mortar }\end{array}$} & \\
\hline & & & $(\mathrm{C} * \%)$ & & & \\
\hline 50M3.5 & \multirow{6}{*}{0.5} & \multirow{3}{*}{$\mathrm{M}$} & 0.01 & 3.8 & 3.5 & 570 \\
\hline $50 \mathrm{M} 6.0$ & & & 0.004 & 5.9 & 4.3 & 317 \\
\hline $50 \mathrm{M} 7.5$ & & & 0.02 & 7.4 & 5.9 & 316 \\
\hline $50 \mathrm{~N}$ & & - & - & 3 & 2.4 & 852 \\
\hline 50L6.0 & & $\mathrm{L}$ & 0.005 & 5.6 & 4.7 & 348 \\
\hline 50 S6. 0 & & $S$ & 0.012 & 6.3 & 4.4 & 332 \\
\hline
\end{tabular}

Table 2 Material properties

\begin{tabular}{|c|c|}
\hline Material & Property $\left[\right.$ density $\left.\left(\mathrm{g} / \mathrm{cm}^{3}\right)\right]$ \\
\hline \hline OPC & Ordinary portland cement [3.15] \\
\hline MPC & Moderate heat portland cement $[3.21]$ \\
\hline BFS & Blast furnace $\operatorname{slag}\left(4,200 \mathrm{~cm}^{2} / \mathrm{g}\right)[2.88]$ \\
\hline FA & Fly ash $\left(4,420 \mathrm{~cm}^{2} / \mathrm{g}\right)[2.28]$ \\
\hline SF & Silica fume $\left(18.7 \mathrm{~m}^{2} / \mathrm{g}\right)[2.20]$ \\
\hline W & tap water \\
\hline S & crushed sand $[2.68]$ \\
\hline G & crushed gravel $\left(\mathrm{G}_{\max }=20 \mathrm{~mm}\right)[2.71]$ \\
\hline SP & super plasticizer \\
\hline A & antiforming agent \\
\hline
\end{tabular}

Table 3 Mix-proportion

\begin{tabular}{|c|c|c|c|c|c|c|c|c|c|c|c|c|c|c|}
\hline \multirow{2}{*}{ Mixture } & \multirow{2}{*}{$\mathrm{W} / \mathrm{B}$} & \multicolumn{8}{|c|}{ quantity of material per unit volume $\left(\mathrm{kg} / \mathrm{m}^{3}\right)$} & \multicolumn{2}{|c|}{$\operatorname{Agent}\left(\mathrm{g} / \mathrm{m}^{3}\right)$} & \multirow{2}{*}{\begin{tabular}{|c|} 
Slump \\
$(\mathrm{cm})$
\end{tabular}} & \multirow{2}{*}{$\frac{\text { Air }}{(\%)}$} & \multirow{2}{*}{$\begin{array}{l}\text { concrete } \\
\text { temp. }\left({ }^{\circ} \mathrm{C}\right)\end{array}$} \\
\hline & & $\mathrm{W}$ & $\mathrm{O}$ & $\mathrm{M}$ & $\mathrm{S}$ & G & BFS & FA & $\mathrm{SF}$ & SP & A & & & \\
\hline OPC50 & \multirow{10}{*}{50} & \multirow{10}{*}{165} & 330 & - & \multirow{10}{*}{907} & \multirow{10}{*}{1,034} & - & - & - & 2,640 & 23 & 8.0 & 1.0 & 21.5 \\
\hline MPC50 & & & - & 330 & & & - & - & - & 2,310 & 20 & 10.0 & 1.8 & 24.7 \\
\hline BFS30-50 & & & 231 & - & & & 99 & - & - & 1,815 & 36 & 10.0 & 1.0 & 23.0 \\
\hline BFS45-50 & & & 182 & - & & & 149 & - & - & 1,650 & 30 & 10.0 & 1.9 & 22.9 \\
\hline BFS65-50 & & & 116 & - & & & 215 & - & - & 1,320 & 23 & 10.0 & 1.4 & 22.3 \\
\hline FA10-50 & & & 297 & - & & & - & 33 & - & 2,805 & 26 & 11.0 & 1.7 & 22.5 \\
\hline FA30-50 & & & 231 & - & & & - & 99 & - & 2,145 & 20 & 10.0 & 1.6 & 22.2 \\
\hline SF10-50 & & & 297 & - & & & - & - & 33 & 4,290 & 40 & 11.0 & 1.9 & 23.0 \\
\hline SF15-50 & & & 281 & - & & & - & - & 50 & 3,300 & 40 & 10.0 & 1.9 & 20.4 \\
\hline SF30-50 & & & 231 & - & & & - & - & 99 & 4,290 & 50 & 3.0 & 2.0 & 21.4 \\
\hline
\end{tabular}

$\rightarrow 0.3 \rightarrow 25(55) \rightarrow 0.3 \rightarrow 87(15) \rightarrow 0.3 \rightarrow 406(3) \rightarrow 0.3[\mathrm{MPa}]$ $(\mathrm{nm})$ の圧力サイクルで実施した。（）内の数值は圧入 圧力に対応したおおよその空隙直径を示している。養生 条件、水セメント比、材齢が同一である過去の計測デー 夕に基づき、累積空隙量曲線の折れ曲がり点の前後の圧 力を最大值とする圧力サイクルを設定している。

本手法によって得られた各圧入段階の全圧入量を累積 させると従来の測定手法で得る累積空隙量曲線と一致す る。加圧時に試料内部へ圧入された水銀量を「全空隙」 とし、除圧時に試料内に取り残される水銀量を「インク ボトル空隙」そとて全空隙とインクボトル空隙の差分 を「連続空隙」として取り扱った。

測定には Micromeritics 社製 AutoPore III を使用し、 空隙径の算出には、Washburn 式に接触角 $\theta=130^{\circ}$ 、水 銀の表面張力 $\gamma=484 \mathrm{dyn} / \mathrm{cm}$ を用いた。配合ごと 2 回 の測定を行い、その平均值を試験結果として採用した。 ただ、2 回の測定空隙量曲線が異なる場合には複数回 の再測定を追加し、空隙量曲線がほぼ重なる複数の測定 結果の平均を試験結果とした。試料は上記の円盤試料 をノミとハンマーにより $5 \mathrm{~mm}$ 角程度に破砕し、アセ卜 ンに 24 時間浸漬させた後、ソーダ石灰を敷いた $20{ }^{\circ} \mathrm{C}$ 、 R.H.30 \%のデシケータ内で 1 ケ月間の乾燥を行った。

\section{2 水銀漸次繰返し圧入法で得る連続空隙量と吸水 量・乾燥量の関係}

(1) 供試体概要

使用材料を Table 2 に示し、配合およびフレッシュ 性状を Table 3 に示す。セメントおよび混和材種類の 異なるコンクリートを作製した。混和材の置換はそれぞ れ JIS に定められる A、B、C 種の範囲で行った。配合 のなかで、単位水量 $165 \mathrm{~kg} / \mathrm{m}^{3}$ 、水結合材比 $50 \%$ 、細 骨材量、粗骨材量は一定である。フレッシュ性状はスラ ンプが $10 \pm 2 \mathrm{~cm}$ 、空気量が $2 \%$ 以下となるように高性 能 $\mathrm{AE}$ 減水剂および消泡剂を添加した。

モルタル試料は材龄 28 日まで水中養生を行った $\phi 100$ $\times 200 \mathrm{~mm}$ の円柱コンクリート供試体のモルタル部より、 一辺 $8 \mathrm{~mm}$ 程度の立方体を採取した。吸水試験および 空隙構造分析の前処理にはアセトン浸漬を 24 時間、そ の後に $20{ }^{\circ}$ C、R.H.11 \%のデジケーター内で真空乾燥を 7 日間行った。

（2）吸水量 · 乾燥量の測定

吸水量はアルキメデス法によって脱イオン水中に浸 漬させ $1 、 3 、 12 、 24$ 時間後に測定を行った。また吸水 後の試料を $20{ }^{\circ} \mathrm{C} 、$ R.H.11 \%のデジケーター内に静置 し、乾燥させ $1 、 3 、 12 、 24$ 時間後の乾燥量を測定した。 配合ごとに 3 回の測定を行い、同様の傾向が得られた 

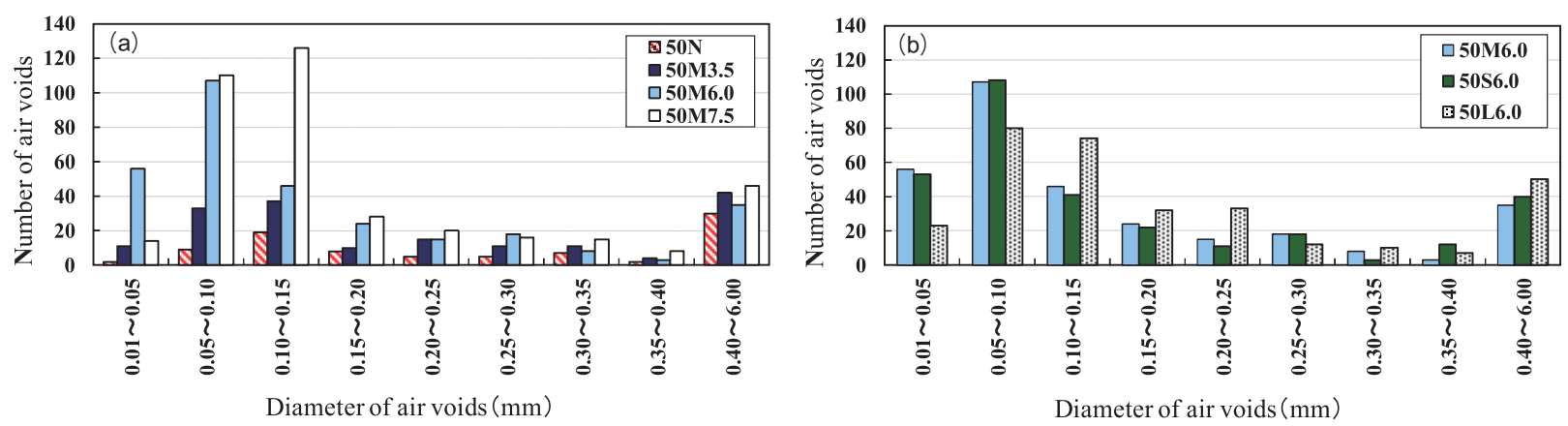

Fig. 1 Relationship between AE agent ( (a) : dosage, (b) : type) and air voids diameter obtained with the linear-traverse method
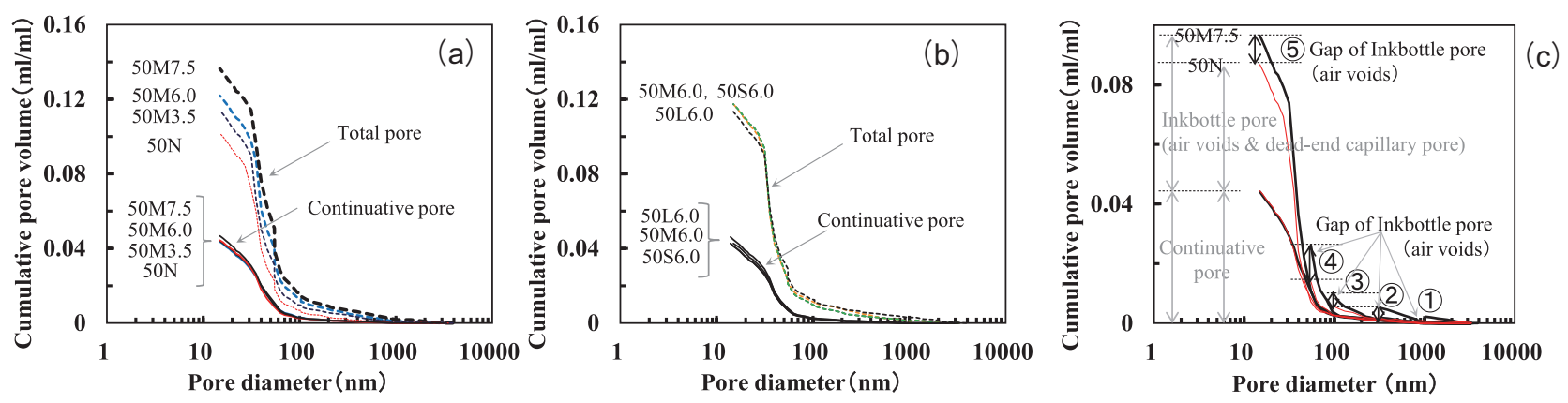

Fig. 2 Difference of air voids amount in cumulative pore volume curves ( (a) : AE agent dosage, (b) : AE agent type), and Gap of air voids volume in each intrusion steps (c)

2 回以上の測定結果の平均值を試験結果として採用した。 (3) 空隙構造分析

試料サイズは $8 \mathrm{~mm}$ 程度であるが、その他の条件は 2.(2)に示した水銀漸次繰返し圧入法と同じである。

\section{3. 水銀の圧入により同定されるインクボトル空隙} とリニアトラバース法により得る空気泡の比較

硬化後の供試体に内包される連行空気の量と寸法を確 認するため、Fig. 1 にリニアトラバース法により得られ た空気泡径分布を示す。同一の $\mathrm{AE}$ 剂 M を使用した場 合、添加量の増加に伴い主に0.01-0.30mm の空気泡の 個数が増加することがわかる。一方、フレッシュ時の目 標空気量を $6 \%$ に設定し、AE 剂種類により空気泡の寸 法を変えようと試みた 3 種類の供試体については、 $\mathrm{AE}$ 剂 L を用いた供試体において 0.05-0.25mm の空気泡 の個数が比較的多くなり、M と S ではほぼ同じ空気泡 径分布が得られた。

Fig. 2(a)に AE 剂 M の添加量を変化させた 4 種類 の供試体の累積空隙量曲線を示す。 $\mathrm{AE}$ 剂無添加の供試 体を基準とすると、添加量に伴い全空隙量は増加した。 一方、連続空隙量は $\mathrm{AE}$ 剂添加量によらず、ほぼ一致 している。

Fig. 2(b)にフレッシュ時の目標空気量を $6 \%$ に設定 し、 $\mathrm{AE}$ 剂種類により空気泡の寸法を変えた 3 種類の 供試体の累積空隙量曲線を示す。Fig. 1 で確認した通り、 全空隙量および連続空隙量はともに、AE 剂種類によら
ずほぼ一致する。なかでも M と S ではほぼ同一の累積 空隙量曲線が得られた。

(a)、（b）の両図における連続空隙の累積空隙曲線で は、100nm 以上の空隙が少ないことが確認できる。こ こで観察された $100 \mathrm{~nm}$ 以下の連続空隙は、外部水和生 成層内の毛管空隙網における連続した経路を捉えている と考えている。

Fig. 2(c)に 50N および 50M7.5 の各圧入段階におけ る圧入曲線を示す。前述の通り、両試料の連続空隙曲線 は一致する。そして各圧入段階において $\mathrm{AE}$ 剂の添加 50M7.5 と 50N の空隙量に差が生じていることがわか る。両試料の供試体諸元において $\mathrm{AE}$ 剂の添加量のみ が異なることから、上記の空隙量の差は純粋な空気量の 差がインクボトル空隙量の差として表れたことが考えら れる。

50N を基準として差し引きにより、閉塞した毛管空隙 など空気泡以外のインクボトル空隙を排除して算出され た值を、空気泡のみを純粋に抽出したインクボトル空隙 量とみなし Fig. 3 に示す。図(a)の $\mathrm{AE}$ 剂 $\mathrm{M}$ を使用し た供試体に着目すると、 $\mathrm{AE}$ 剂添加量の増加に伴い空気 泡を捉えたと考えられるインクボトル空隙量も増加して いることがわかる。100nm 以下の範囲においてインクボ トル空隙が多く検出されている。前述した通り、連続空 隙は 100nm 以下において多く観察される。前述の結果 は、この $100 \mathrm{~nm}$ 以下の連続空隙に接続した空気泡が多く、 $100 \mathrm{~nm}$ 以下の内部水和生成層内の毛管空隙を通らない 

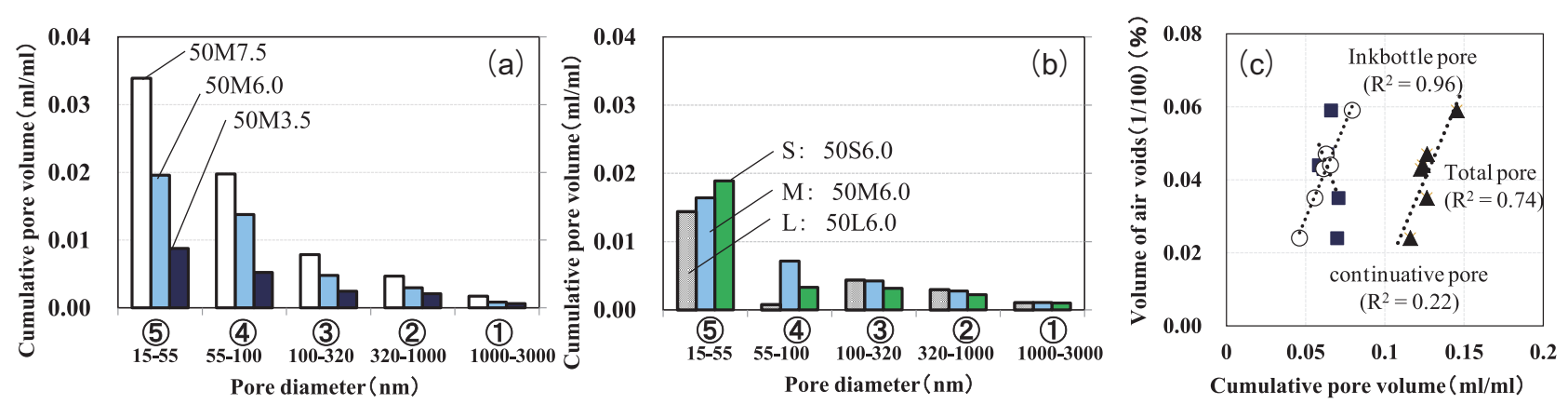

Fig. 3 Difference of air voids amount in each intrusion steps ( (a) : AE agent dosage, (b) : AE agent type), and Relationship between air voids volume and pore volume (c)
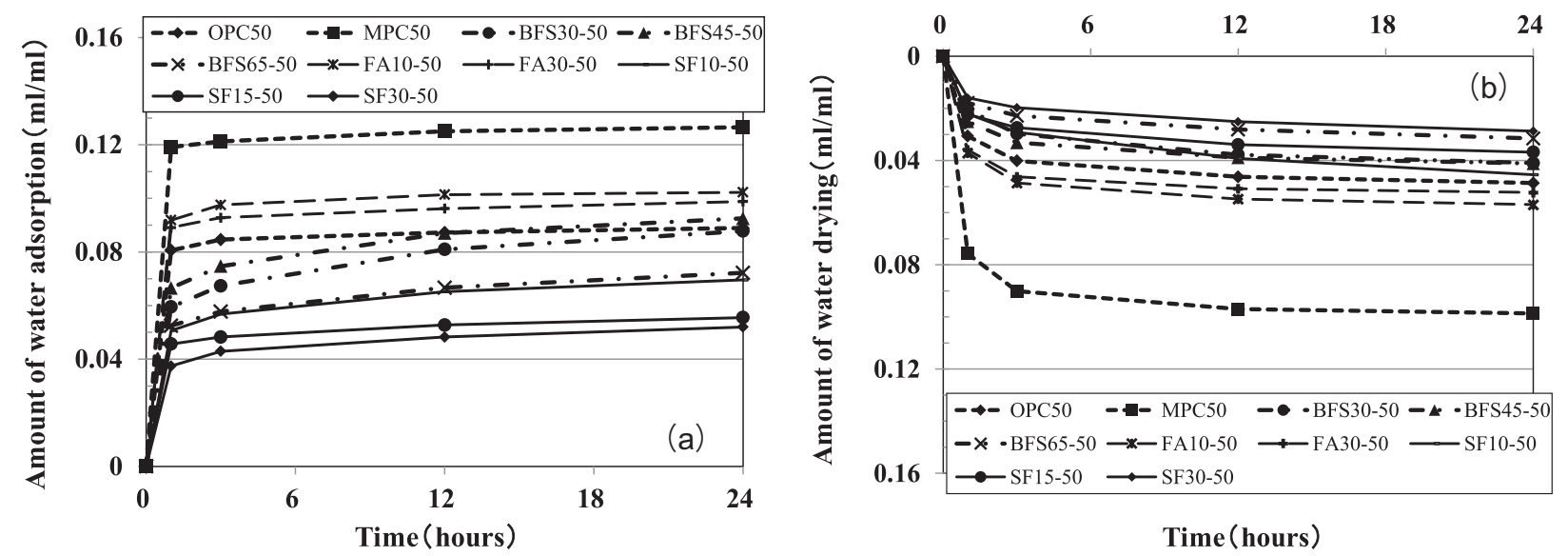

Fig. 4 Change in the amount of water adsorption (a), and drying (b)

と空気泡にアクセスできないことを示唆している。

一方、同図(b)のフレッシュ時の目標空気量を $6 \%$ に 定め、AE 剂種類により空気泡の寸法を变えた 3 種類 の供試体については、Fig. 2(b)の結果と同様、AE 剂の 種類による明確な差異は見られなかった。

Fig. 3(c) に画像解析で捉えた空気量と水銀圧入で取得 した各種空隙における累積量の相関関係を示す。困にお いて、水銀圧入によって得た各種空隙量の決定係数を見 ると、連続空隙では 0.22 とほぼ相関関係は見られず、 全空隙量において 0.74 とやや高い值となり、またイン クボトル空隙量では 0.96 と非常に強い相関関係がある ことを示した。ここで得られた結果は、閉塞した毛管空 隙など空気泡以外のインクボトル空隙の分離方法につい て検討する必要はあるが、水銀圧入で得るインクボトル 空隙から空気泡を抽出する可能性を示している。

\section{4. 水銀漸次繰返し圧入法で得る連続空隙量と吸水 量・乾燥量の関係}

\section{1 モルタル硬化体における吸水・乾燥現象}

Fig. 4(a) に吸水量の経時変化、同図 (b)に乾燥量の経 時変化を示す。吸水量の経時変化は全ての配合で、吸 水開始から 1 時間において最大の傾きが観察される。 1 時間以降の吸水量曲線は、BFS30-50、BFS45-50 では 1-12 時間において緩やかな傾きとなり、その他の試料
では 1 時間以降にほぼ水平な直線が描かれている。一方、 乾燥量の経時変化では、乾燥開始より 1 時間において 最も大きな直線の傾きが確認でき、その後 3 時間まで やや大きな乾燥量が確認できる。3 時間以降、乾燥量の 変化を示す曲線は水平に近づく。

これらのことから、8mm 角のモルタル試料において、 吸水量および乾燥量の変化が微小となるために必要な時 間は、それぞれ 1 時間と 3 時間であることが確認できる。

\section{2 モルタル硬化体の空隙構造}

水銀漸次繰返し圧入法によって得た累積空隙量曲線を Fig. 5 に示す。セメント種類、混和材の種類と置換率に 関して累積空隙量曲線を見る。本研究では $0.005 \mathrm{ml} / \mathrm{ml}$ 以上の累積圧入量が確認される空隙径をしきい空隙径と 定義する。配合条件によらず、しきい空隙径は数千 nm に観察される。ただし SF30 については 3,000-4,000nm における圧入量が SF10、SF15 よりも大きい。配合条 件の差異は、100nm 以下に表れた折れ曲がり点の位置 と累積空隙量に確認できる。100nm 以下に現れた差異 について 4.3 において検討を行うため、10、40、100nm を最小空隙直径とし、各空隙径以上の累積值を Table 4 にまとめた。

全空隙の累積曲線において配合による折れ曲がり点を 比較すると、OPC では 40-50nm、MPC では 50-60nm、 BFS では 20-30nm、FA では 50-60nm、SFでは 20- 

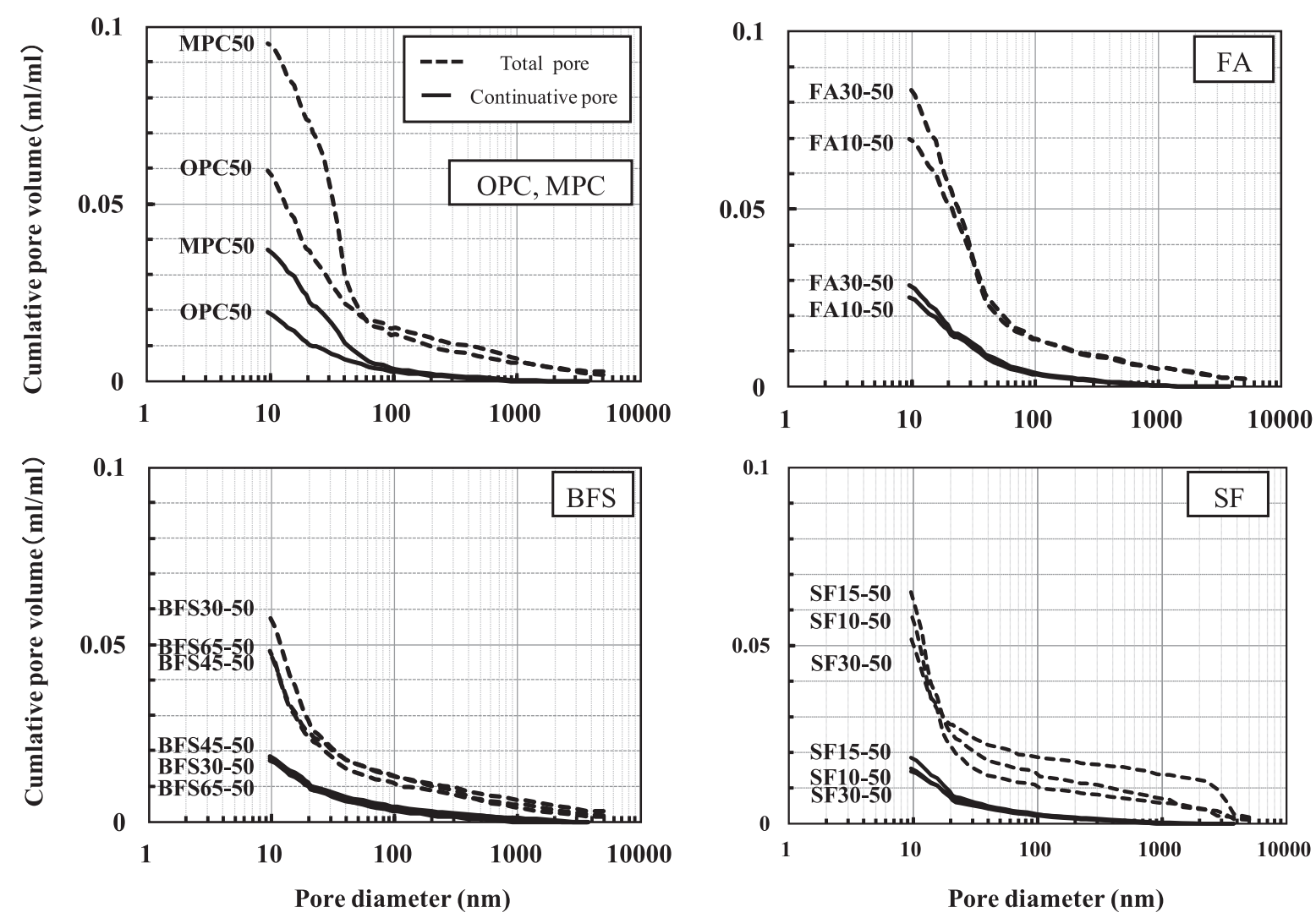

Fig. 5 Cumulative pore volume determined with the step-by-step MIP

Table 4 Summary of cumulative pore volume

\begin{tabular}{|c|c|c|c|c|c|c|}
\hline \multirow{3}{*}{ Mixture } & \multicolumn{6}{|c|}{ Cumulative volume $(\mathrm{ml} / \mathrm{ml})$} \\
\hline & \multicolumn{2}{|c|}{ over 10nm } & \multicolumn{2}{|c|}{ over $40 \mathrm{~nm}$} & \multicolumn{2}{|c|}{ over 100nm } \\
\hline & Total & Continuative & Total & Continuative & Total & Continuative \\
\hline OPC50 & 0.0592 & 0.0194 & 0.0218 & 0.0061 & 0.0148 & 0.0028 \\
\hline MPC50 & 0.0944 & 0.0359 & 0.0297 & 0.0108 & 0.0132 & 0.0034 \\
\hline BFS30-50 & 0.0579 & 0.0177 & 0.0175 & 0.0057 & 0.0128 & 0.0031 \\
\hline BFS45-50 & 0.0478 & 0.0183 & 0.0176 & 0.0069 & 0.0131 & 0.0043 \\
\hline BFS65-50 & 0.0481 & 0.0171 & 0.0151 & 0.0060 & 0.0110 & 0.0038 \\
\hline FA10-50 & 0.0697 & 0.0253 & 0.0237 & 0.0080 & 0.0135 & 0.0034 \\
\hline FA30-50 & 0.0844 & 0.0285 & 0.0261 & 0.0091 & 0.0135 & 0.0038 \\
\hline SF10-50 & 0.0591 & 0.0155 & 0.0135 & 0.0042 & 0.0099 & 0.0022 \\
\hline $\mathrm{SF} 15-50$ & 0.0651 & 0.0186 & 0.0177 & 0.0049 & 0.0132 & 0.0026 \\
\hline SF30-50 & 0.0521 & 0.0155 & 0.0221 & 0.0044 & 0.0185 & 0.0022 \\
\hline
\end{tabular}

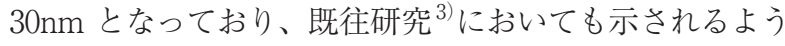
に $100 \mathrm{~nm}$ 以下の空隙にはセメント種類や混和材の反応 性や、粒子サイズの違いも現れていることが確認できる。

つぎに累積空隙量を比較する。折れ曲がり点が比較的 大径であった MPC、FA では累積空隙量も大きく、折 れ曲がり点が小径であった BFS、SF では累積空隙量も 小さいことがわかる。

次項では、ここで示した累積空隙量と吸水および乾燥 量の関係について検討を行い、水銀漸次繰返し圧入法で 得る連続空隙と吸水·乾燥量の関係について考察を行う。
4. 3 モルタル硬化体における吸水・乾燥性状と水銀圧入 法によって得る空隙構造の関係

Fig. 6、Fig. 7 に吸水量と水銀漸次繰返し圧入法で 測定される全空隙量および連続空隙の関係を、Fig. 8、 Fig. 9 に乾燥量と全空隙量および連続空隙量との関係を 示す。図の左側から、1、3、12、24 時間の吸水量と累 積空隙量の関係を示した。また空隙量は Table 4 にま とめた 10、40、100nm を最小空隙直径とする累積值を 用いて比較した。最小空隙直径は、本測定において試料 変形が確認されない圧力範囲における最小空隙直径と 

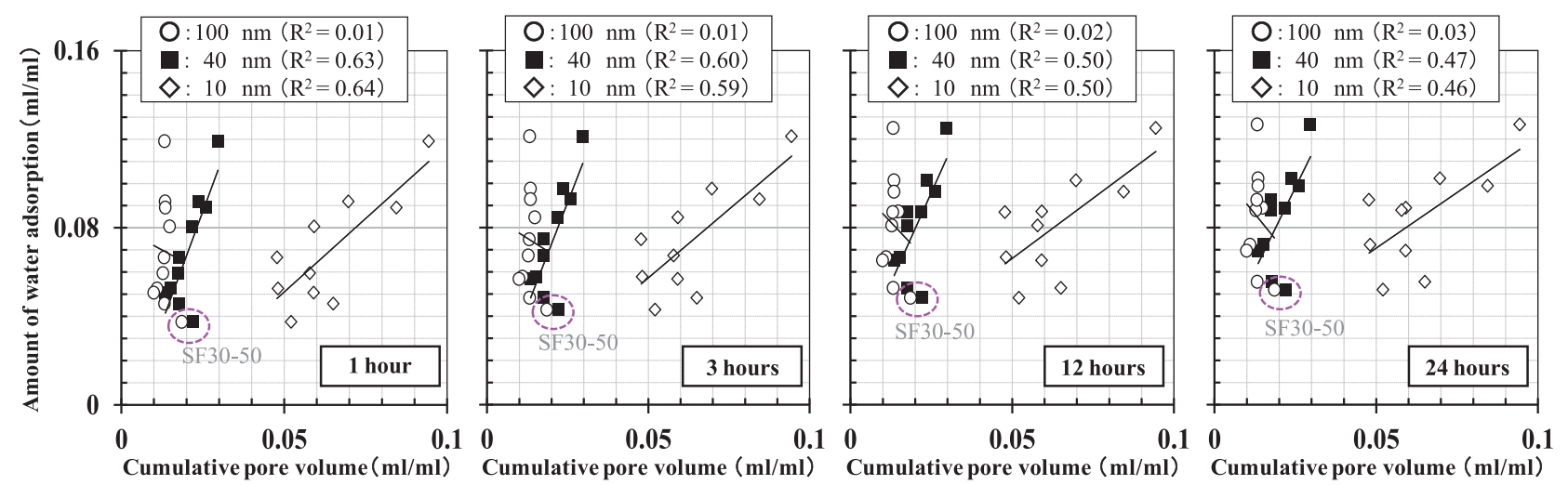

Fig. 6 Relationship between amount of water adsorption and cumulative pore volume (total pore)
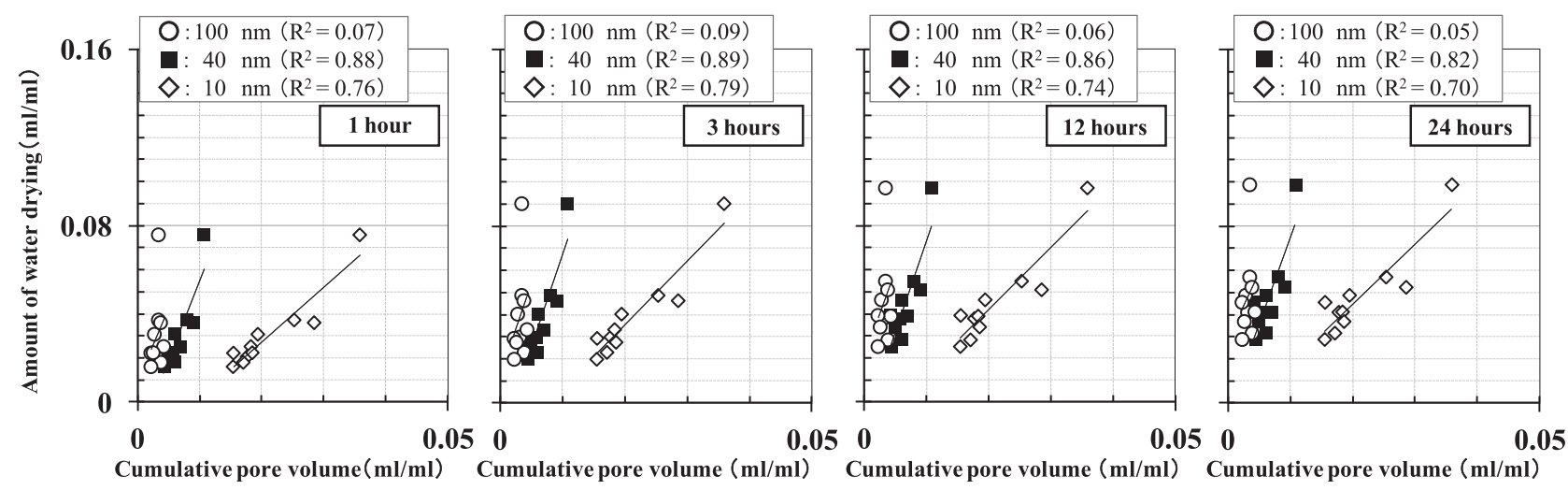

Fig. 7 Relationship between amount of water adsorption and cumulative pore volume (continuative pore)

して10nm を、前述した折れ曲がり点の中央值として 40nm を、また連続空隙曲線のしきい空隙径以上の值と して 100nm を選定した。

Fig. 6 において、まず吸水量と全空隙量の関係を見 る。グラフの凡例中に示した決定係数 $\mathrm{R}^{2}$ を見ると、吸 水 1 時間の図における $10 \mathrm{~nm}$ 以上の空隙量との関係が示 す 0.64 が最も高い值となった。同図の $40 \mathrm{~nm}$ 以上の全 空隙量においても、0.63 と近い值が示された。一般的に 決定係数が 0.60 以上であると相関関係があると言われ ており、全空隙と吸水量の間にはやや相関関係があると いう程度にとどまった。100nm 以上の全空隙量との間に おける決定係数は小さく、関係性が弱いことがうかがえ る。また吸水時間による決定係数の変化について見てい くと、1 時間で最も高く、時間が経つに連れ減少していく。

つぎに Fig. 7 において吸水量と連続空隙量の関係に ついて見てみる。全空隙量と同様に、吸水 1 時間にお いて、10nm 以上、40nm 以上の連続空隙量との間に 最も高い決定係数が得られた。得られた決定係数は、 $40 \mathrm{~nm}$ 以上の連続空隙量の方がやや高く、0.88 となった。

全空隙と同様に、連続空隙においても 100nm 以上の 累積空隙量と吸水量の間には関係性が見出せない。いず れの時間においても、連続空隙では 0.84-0.88の高い 決定係数が得られている。全空隙の決定係数が連続空隙 のそれよりも小さくなる理由は、吸水量が最小である
SF30 の全空隙量が近似曲線から右側に外れていること にある。Fig. 5 における SF30 の全空隙曲線に観察され た 3,000nm の粗大な空隙が影響しており、このような 空隙を排除することにより連続空陌の決定係数は向上し ていると考えられる。

Fig. 8 において乾燥量と全空隙量の関係を見る。 $\mathrm{R}^{2}$ の最大值は 1 時間と 3 時間における $10 \mathrm{~nm}$ 以上の全空 隙量で 0.74 であった。吸水量との関係と同様、100nm 以上の全空隙量との間には関係性が見出させていない。

Fig. 9 において乾燥量と連続空隙量との関係を見る と、100nm 以上の連続空隙と乾燥量の間には関係性が ほぼ無いことがわかる。また、10nm 以上の連続空隙の 決定係数はいずれの時間においても 0.82-0.89 となり、 3 時間において最大值を得た。

累積空隙量との間に最も高い決定係数が得られた時間 は、吸水量では 1 時間、乾燥量では 3 時間であった。 4.1 で前述したように、それぞれの時間では、8 $\mathrm{mm}$ のモル 夕ル試料において吸水量、乾燥量の変化が微小となり、 吸水・乾燥開始直後から観察できる急激な質量変化が完 了する。水銀漸次繰返し圧入法で測定される連続空隙と は、吸水開始から 1 時間までに吸水され、乾燥開始か ら 3 時間までに乾燥される、急激な吸水・乾燥現象に 関与する空隙であることが、上記の検討結果から示唆さ れた。 

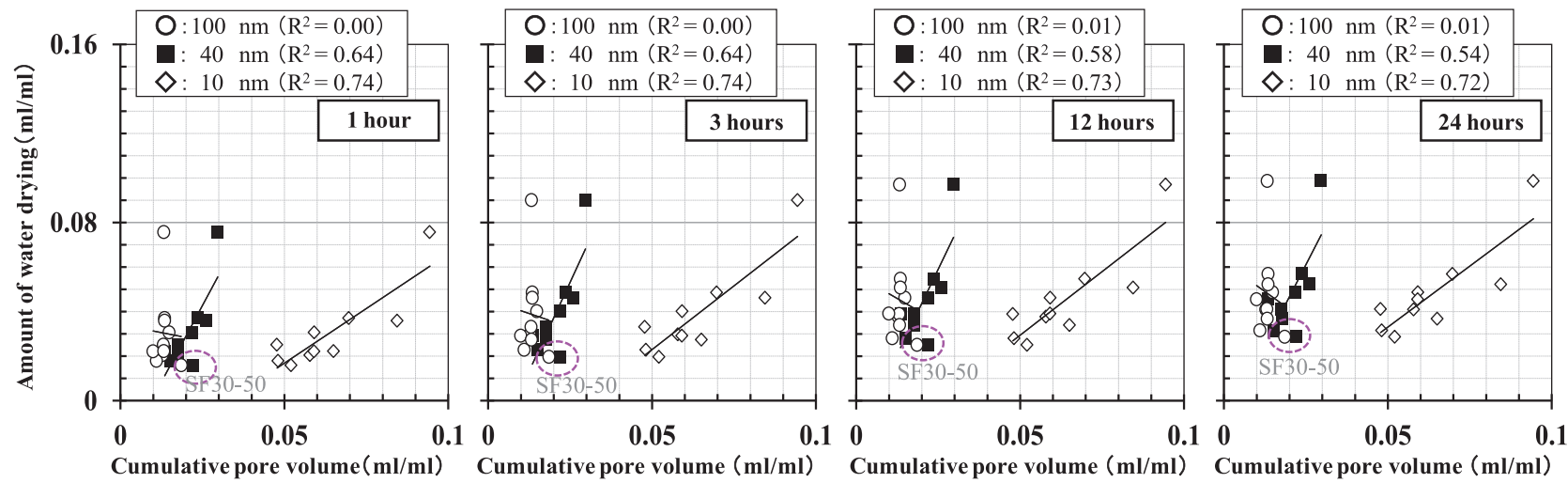

Fig. 8 Relationship between amount of water drying and cumulative pore volume (total pore)
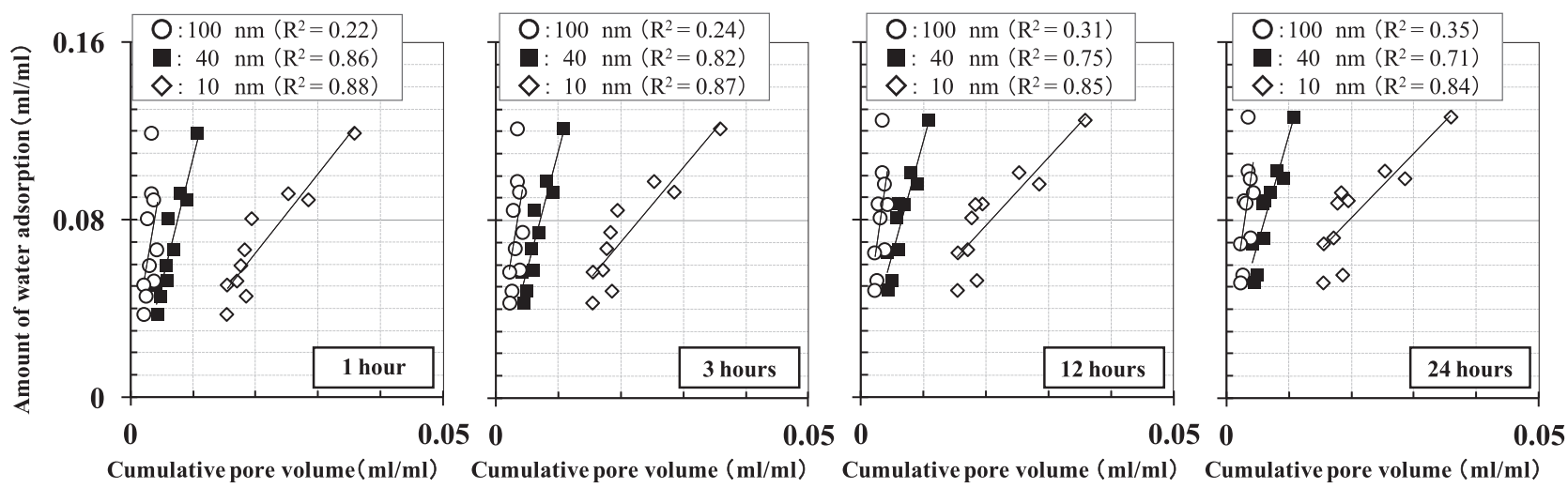

Fig. 9 Relationship between amount of water drying and cumulative pore volume (continuative pore)

\section{5. まとめ}

モルタル硬化体を対象として、水銀漸次繰返し圧入法 で得るインクボトル空隙と連続空隙の実態を把握するた め、それぞれの空隙について、リニアトラバース法で得 る空気泡量および吸水・乾燥過程における質量変化との 量的関係を検討した。

水銀漸次繰返し圧入法で得るインクボトル空隙と空気 泡の関係については、量と寸法を調整したモルタル硬化 体を用いて、上記の画像解析手法により算出される硬化 後の空気泡の量と寸法の情報を抽出できるか検討した。 インクボトル空隙量と空気泡の量との間には高い相関が 認められた。水和の進行により閉塞した毛管空隙など空 気泡以外のインクボトル空隙の分離については検討を要 するが、本研究で得られた結果には空気泡の量をインク ボトル空隙量として同定できる可能性が示された。

水銀漸次繰返し圧入法で得る連続空隙については、モ ルタル試料における吸水現象、乾燥現象における水分 移動挙動との関係を検証した。1 辺 $8 \mathrm{~mm}$ 程度の試料に おける吸水現象では、浸漬開始 1 時間程度まで急速な 吸水が確認でき、1 時間以降 24 時間まで僅かな吸水が 続くことが確認できた。また、乾燥現象では試験開始 1 時間まで急激な乾燥が進み、その後 3 時間までは比 較的大きな乾燥量が確認でき、3 時間以降 24 時間まで は僅かな乾燥量が計測された。連続空隙は、それぞれの
現象において質量変化が頭打ちとなる時間 (吸水現象で は 1 時間、乾燥現象では 3 時間)の吸水量・乾燥量との 間に強い相関関係を見出すことができた。この結果は、 移動媒体は異なるが、水銀の圧入 · 排出が可能である連 続空隙が、吸水・乾燥が容易に行われる水の移動経路の 一部を捉えている可能性を示している。

\section{謝辞：}

本研究ではリニアトラバース試験機の捧借、空気泡の 調整に関して竹本油脂株式会社 齊藤和秀氏に御協力を 頂きました。ここに記し、深く御礼申し上げます。

\section{参考文献：}

1) P. K. Mehta and D. Manmohan : Pore size distribution and permeability of hardened cement pastes, Proceedings of the $7^{\text {th }}$ International congress on the Chemistry of Cements, Vol. 3 (1980)

2) S. Diamond : Mercury porosimetry : An inappropriate method for the measurement of pore size distributions in cement-based materials, Cement and Concrete Research, Vol. 30, pp. 1517-1525 (2000)

3） 浅賀喜与志ほか：粒径をそろえた各種ポルトランド セメントの水和反応と硬化組織、セメント・コンク 
リート論文集、No. 54、pp. 8-14（2000）

4) R. Yoshida and T. Kishi : Proposal of a new approach for determination of pore continuity and suitable intrusion pressure based on step-by-step mercury intrusion porosimetry test., 1st International conference on Microstructure Related Durability of Cementitious Composites, Vol. 2, pp. 14551464 (2008)

\title{
DISCUSSION ON AN INK-BOTTLE PORE AND A CONTINUATIVE PORE OBTAINED BY STEP-BY-STEP MERCURY INTRUSION POROSIMETRY TEST ON HARDENED MORTAR
}

\author{
Ryo YOSHIDA*1, Kohei MIZUNO*2, Toshiharu KISHI*3 and Hidetaka UMEHARA*2 \\ *1 NAGOYA INSTIUTE OF TECHNOLOGY, Department of civil engineering (Gokiso-cho, \\ Showa-ku, Nagoya-shi, Aichi 466-8555, Japan) \\ *2 NAgOYA INSTiUte OF TEChNOLOGY, Department of Scientific and Engineering \\ Simulation (Gokiso-cho, Showa-ku, Nagoya-shi, Aichi 466-8555, Japan) \\ *3 UNIVERSITY OF TOKYO, Institute of Industrial Science, Department of Human and Social \\ Systems (4-6-1, komaba, Meguro-ku, Tokyo 153-8505, Japan)
}

\begin{abstract}
The relationship between the air volume obtained through the linear-traverse method and the amount of water absorption or drying was verified for the inkbottle pore volume and the continuative pore volume obtained through the step-by-step MIP method. As for the relationship between inkbottle pores obtained through the MIP method and air voids, the possibility of evaluate the information on air voids volume and size calculated through the liner-traverse method was examined using hardened mortar. A high correlation was confirmed between the volume of inkbottle pores and the volume of air voids. As for continuative pores obtained through the MIP method, their relationship of water absorption and drying in mortar samples was verified. In the water absorption phenomena, a rapid water absorption until about 1 hour after the start of soak and the continuation of slight water absorption until 24 hours after that could be observed. In the drying phenomenon, moreover, the rapid drying proceeds up to 1 hour after the start of the test, and then the relatively larger amount of drying was confirmed up to 3 hours, and a slight amount of drying was measured from 3 hours until 24 hours. For continuative pores obtained through the MIP method, a strong correlation could be found with the amount of water absorption in 1 hour for the water absorption phenomenon and the amount of drying in 3 hours for the drying phenomenon.
\end{abstract}

KEY WORDS : Mercury intrusion porosimetry, Inkbottle, Air voids, Linear-traverse method, Water absorption 